\title{
Penerapan Model Penemuan Terbimbing Untuk Meningkatkan Keterampilan Proses Sains dan Hasil Belajar Siswa di SMAN 1 Kota Bengkulu
}

\author{
Annisa Apriani Widya Ningsih, Indra Sakti, Nyoman Rohadi \\ Program Studi Pendidikan Fisika FKIP-UNIB \\ Email :Annisawidya46@gmail.com
}

\begin{abstract}
ABSTRAK
Penelitian ini bertujuan untuk mendeskripsikan peningkatan aktivitas belajar, menjelaskan peningkatan hasil belajar dan mendeskripsikan keterampilan proses sains siswa. Subjek dalam penelitian ini adalah seluruh siswa kelas X MIA-1 SMAN 1 Kota Bengkulu yang berjumlah 30 Orang. Hasil penelitian ini menunjukan bahwa rata-rata aktivitas belajar siswa pada siklus I adalah sebesar 23 dalam kategori cukup, siklus II sebesar 25,5 dalam kategori baik, dan siklus III sebesar 28,5 dalam kategori baik. Hasil belajar pada siklus I diperoleh daya serap sebesar 73\% dan ketuntasan belajar klasikal sebesar 50\%, meningkat pada siklus II yaitu daya serap sebesar $83,5 \%$ dan ketuntasan belajar klasikal sebesar 86,6\%, dan meningkat lagi untuk siklus III daya serap sebesar 90,08\% dan ketuntasan belajar sebesar $100 \%$. Rata-rata keterampilan proses sains siswa secara keseluruhan indikator pada siklus I sebesar 13 dalam katagori cukup, siklus II sebesar 16 dalam katagori baik dan siklus III sebesar 18 dalam katagori baik. Berdasarkan hasil penelitian bahwa penerapan model Penemuan terbimbing kelas X MIA-1 di SMAN 1 kota Bengkulu dapat meningkatkan aktivitas belajar, hasil belajar dan keterampilan proses sains siswa.
\end{abstract}

Kata Kunci : Model Penemuan terbimbing (guided discovery), aktivitas belajar siswa, hasil belajar siswa, keterampilan proses sains siswa.

\begin{abstract}
This research was aimed to describe the improvement of Learning Activity, explained the improvement of Learning result and to describe Student's ability on science process. The Subjects of this research were all students at grade $\mathrm{x}$ Sciene 1 Senior High School Number one Bengkuku City. They are 30 Students. The result showed tha the average of student's learning activity at first cycle was 23 was in enough category, second cycle was 25.5 was in good category, and thr third cycle was 28.5 was in good category. The Learning result at first cycle was gotten $73 \%$ absorption and the clasical learning completeness was $50 \%$, it increased in the second cycle was $83,5 \%$ for the absorption and $86,6 \%$ for the clasical Learning completeness, and so increased at the last cycle was $99.08 \%$ for the absorption and $100 \%$ for the Learning Completeness. The average of Student's science process ability in general indicator at first cycle was 13 in enought category, at second cycle was 16 in good category and at last cycle was 18 in good category. Based on the research result, the apply of 'Guide Discovery' Learning method at grade x Science 1 at Senior High School Number 1 Bengkuku City can improve the Student's Learning activity, Learning result and the student's science process ability.
\end{abstract}

Keyword: Guided Discovery Method, Student's learning activity, student's learning result, Student's science process ability

\section{PENDAHULUAN}

Pembelajaran merupakan suatu sistem yang terdiri dari berbagai komponen. Komponen utama dalam sebuah pembelajaran adalah siswa yang berkedudukan sebagai subjek belajar dan guru sebagai fasilitator pembelajaran. Guru sebagai fasilitator dalam pembelajaran sangat menentukan bagaimana siswa sebagai subjek belajar melakukan aktivitas untuk meningkatkan kemampuannya [1]. Pada proses pembelajaran di sekolah, guru membantu siswa dalam pengembangan potensi yang dimiliki untuk meningkatkan ranah pengetahuan, sikap dan keterampilan. Terutama bagi siswa kelas $\mathrm{X}$ yang baru saja memasuki jenjang Sekolah Menengah Atas, Salah satunya melalui mata pelajaran fisika. Proses pembelajaran fisika di kelas $\mathrm{X}$ ini dalam proses pembelajarannya melakukan kegiatan pengamatan, pengukuran dan eksperimen untuk mendapatkan fakta, konsep dan prinsip-prinsip fisika.

Berdasarkan observasi dan wawancara langsung dengan guru fisika di SMA Negeri 1 Kota Bengkulu, sekolah ini memiliki 5 kelas X MIA. Hasil pengamatan di kelas X MIA-1 terdapat beberapa hal yang diamati saat mata pelajaran fisika berlangsung, diantaranya : 1) hasil belajar fisika pada aspek pengetahuan masih kurang, hal ini terlihat dari hasil ulangan harian dan ulangan akhir semester yaitu hanya berada pada kisaran 40\% Siswa yang tuntas berdasarkan ketuntasan minimal 75,2) belum terlihatnya aktivitas yang mendominasi Siswa pada saat pelaksanaan pembelajara, karena Siswa hanya menerima informasi dari guru dan 
terkadang tidak memperhatikan penjelasan yang diberikan oleh guru, 3) Siswa belum terampil dalam menemukan fakta atau konsep dengan baik pada saat melakukan percobaan atau praktikum, sehingga Siswa belum mandiri dalam melakukan suatu percobaan yang sesuai dengan prosedur kerja, 4) saat pelaksanaan praktikum tidak semua siswa melakukan pengamatan atau observasi, siswa juga belum tahu cara mengklasifikasi, memprediksi, mengukur, menyimpulkan dan mengkomunikasikan sehingga belum terlihatnya keterampilan proses sains Siswa, 5) Siswa juga belum tahu cara merumuskan masalah, mengumpulkan informasi, memproses serta menganalisis data sehingga proses pembelajaran dikelas menjadi pasif dan guru yang lebih aktif dalam memberikan informasi.

Melalui fakta yang terjadi di lapangan tersebut tentunya telah menimbulkan permasalahan di dalam kelas. Khususnya ini terjadi di kelas X MIA-1 di SMA Negeri 1 Kota Bengkulu. Hal ini perlu adanya perbaikan melalui beberapa solusi diantaranya dengan menggunakan model yang tepat pada pembelajaran untuk meningkatkan hasil belajar dan keterampilan proses sains sehingga mendapatkan hasil yang baik. Penggunaan model pembelajaran yang tepat akan membuat tercapainya suatu tujuan pembelajaran. Untuk membuat Siswa mampu meningkatkan hasil belajar dan keterampilan proses sainsnya, maka dibutuhkan model pembelajaran yang tepat. Pada mata pelajaran fisika, siswa membutuhkan model yang membuat siswa melakukan aktivitas seolah-olah dirinya adalah ilmuwan.

Untuk melakukan aktivitas tersebut perlu dilakukuan langkah-langkah ilmiah, yaitu merumuskan masalah, mengajukan hipotesis, mengumpulkan data, mengolah data, menganalisis data, dan membuat kesimpulan. Maka dari itu dipilih model Penemuan terbimbing dikarenakan model ini akan membuat Siswa belajar aktif menemukan pengetahuan sendiri melalui suatu percobaan dengan langkah-langkah yaitu merumuskan masalah, mengumpulkan, menyusun, memproses dan menganalisis data, menyusun prakiraan, verbalisasi prakiraan serta evaluasi. Selain itu, model ini sering diterapkan percobaan sains di laboratorium dengan pengawasan guru, sehingga pada saat aktivitas belajar tidak hanya akan meningkatkan aspek kognitif saja tetapi juga aspek psikomotorik karena ada keterampilan proses sains pada saat pelaksanaan proses pembelajaran. Berdasarkan hal tersebut maka digunakan model Penemuan terbimbing.

Model Penemuan terbimbing ialah bagian dari model discovery learning. Discovery learning adalah menemukan konsep melalui serangkaian data atau informasi yang diperoleh melalui pengamatan atau percobaan. Guided discovery ini atau penemuan terbimbing merupakan metode yang digunakan untuk membangun konsep di bawah pengawasan guru. Pembelajaran kognitif yang menuntut guru lebih kreatif menciptakan situasi yang dapat membuat siswa belajar aktif menemukan pengetahuan sendiri.

Hasil penelitian yang menggunakan model penemuan terbimbing, salah satunya yaitu penelitian Rachyuni (2015) juga menyatakan bahwa pembelajaran guided discovery dapat meningkatkan hasil belajar dan keterampilan proses sains. Oleh karena itu, dirasa perlu diadakan penelitian yang berjudul "Penerapan Model Penemuan terbimbing Untuk Meningkatkan Hasil Belajar dan Keterampilan Proses Sains siswa Kelas X MIA-1 di SMA Negeri 1 Kota Bengkulu". Penelitian ini untuk mengetahui apakah model pembelajaran Penemuan terbimbing dapat meningkatkan Hasil Belajar dan keterampilan proses sains siswa di kelas X MIA-1 SMA Negeri 1 Kota Bengkulu. Pelaksanaan penelitian ini sesuai dengan kurikulum yang telah diterapkan di SMA Negeri 1 Kota Bengkulu yaitu kurikulum 2013 yang menekankan pada pendekatan saintifik.

Sesuai rumusan masalah yang telah ditetapkan, maka tujuan dari penelitian ini adalah (1) Mendeskripsikan peningkatkan aktivitas belajar siswa pada materi getaran harmonik di kelas X MIA-1 SMA Negeri 1 Kota Bengkulu, (2) Menjelaskan peningkatan hasil belajar siswa dalam pembelajaran fisika dengan model pembelajaran penemuan terbimbing pada materi getaran harmonik di kelas X MIA-1 SMA Negeri 1 Kota Bengkulu, (3) Mendeskripsikan keterampilan proses sains siswa setelah pembelajaran fisika dengan model pembelajaran 
penemuan terbimbing pada materi getaran harmonik di kelas X MIA-1 SMA Negeri 1 Kota Bengkulu.

\section{METODELOGI PENELITIAN}

Penelitian ini adalah Penelitian Tindakan Kelas (PTK)/Classroom Action Research) yaitu penelitian yang dilakukan oleh guru di dalam kelasnya sendiri melalui refleksi diri dengan tujuan untuk memperbaiki kinerjanya sebagai guru, sehingga hasil belajar siswa menjadi meningkat [2]. Penelitian ini dilaksanakan di SMAN 1 Kota Bengkulu semester II tahun ajaran 2017/2018. Subjek dalam penelitian ini adalah seluruh siswa kelas X MIA-1 SMAN 1 Kota Bengkulu Semester II Tahun 2017/2018 yang jumlahnya 30 siswa, terdiri dari 9 siswa laki-laki dan 21 siswa perempuan. Siswa dikelas ini bersifat heterogen atau memiliki kemampuan yang berbeda-beda.

Teknik pengumpulan data yang digunakan dalam penelitian ini adalah lembar observasi dan tes akhir siklus. Data yang didapatkan adalah aktivitas siswa dan guru, keterampilan proses sains pada setiap siklus. Aktivitas belajar dan keterampilan proses sains diamati menggunakan lembar observasi pada setiap siklusnya. Penilaian lembar observasi berpedoman pada kriteria penilaian lembar observasi. keterampilan proses sains diajarkan melalui lembar kerja siswa dan untuk melihat hasil belajar siswa pada akhir siklus diberikan soal tes evaluasi. Tes evaluasi terdiri dari empat soal essay yang menggunakan tingkatan kognitif C3 dan C4, yaitu menerapkan dan menganalisis. Aktivitas belajar siswa dan aktivitas guru merupakan penilaian observasi dari dua orang pengamat. Dengan kisaran nilai dalam kategori seperti pada tabel 1.

Tabel 1. Interval Kategori penilaian observasi aktivitas belajar peserta didik dan guru

\begin{tabular}{|c|c|}
\hline Interval & Katagori \\
\hline $1-1,6$ & Kurang \\
\hline $1,7-2,3$ & Cukup \\
\hline $2,4-3,0$ & Baik \\
\hline
\end{tabular}

Keterampilan proses sains dianalisis berdasarkan tahap-tahap dalam keterampilan proses sains yang dilakukan oleh siswa dan diamati oleh dua orang pengamat melalui lembar observasi berdasarkan rubrik penilaian. Kategori kemampuan pemecahan masalah dapat dilihat pada tabel 2.:

Tabel 2. Kategori Keterampilan Proses Sains

\begin{tabular}{|c|c|}
\hline Rentang & Kategori \\
\hline $6-9$ & Kurang \\
\hline $10-13$ & Cukup \\
\hline $14-18$ & Baik \\
\hline
\end{tabular}

Data tes dianalisa dengan menggunakan rata-rata nilai dan kriteria ketuntasan berdasarkan penilaian patokan menurut Permendikbud No. 104 Tahun 2014. Secara klasikal proses belajar mengajar dikatakan berhasil atau tuntas apabila Siswa dikelas memperoleh nilai $\geq 75$ sebanyak $80 \%$. Untuk melihat peningkatan hasil belajar tersebut dapat digunakan rumus sebagai berikut :

\section{a. Konversian Skor ke Nilai}

$$
\text { Nilai }=\frac{\text { Jumlah Skor Perolehan }}{\text { Jumlah Skor Maksimal }} \times 100
$$

b. Nilai Rata-rata [3]

$$
\bar{x}=\frac{\sum x}{N}
$$

Keterangan:

$\bar{X} \quad=$ nilai rata-rata 


$$
\begin{array}{ll}
\sum X & =\text { jumlah nilai } \\
N & =\text { jumlah Siswa }
\end{array}
$$

c. Standar Deviasi [4]

Untuk menghitung standar deviasi menggunakan rumus:

Dimana :

$$
S=\sqrt{\frac{(X-\bar{X})^{2}}{N-1}}
$$

$S=$ Standar deviasi

$\mathrm{X}=$ Nilai siswa

$\bar{X}=$ Nilai rata-rata

$\mathrm{N}=$ Jumlah siswa

\section{d. Daya Serap Klasikal}

Daya serap klasikal menyatakan tingkat kemampuan penguasaan konsep Siswa yang diperoleh dari tes pengetahuan. Daya serap ini dapat diukur dengan

$$
D S=\frac{N S}{S \times N I} \times 100 \%
$$

Keterangan:

DS = daya serap siswa

NS = jumlah nilai seluruh siswa

$\mathrm{S}=$ jumlah Siswa dan NI = nilai ideal

\section{d. Ketuntasan Belajar Klasikal}

Ketuntasan belajar secara klasikal menyatakan persentase jumlah siswa yang telah tuntas secara klasikal.

Keterangan :

$$
K B=\frac{N^{\prime}}{N} x 100 \%
$$

$\mathrm{KB}=$ ketuntasan belajar secara klasikal

$\mathrm{N}^{\prime}=$ jumlah siswa yang nilainya $\geq 72$

$\mathrm{N}=$ jumlah siswa keseluruhan

\section{HASIL DAN PEMBAHASAN}

\subsection{Hasil}

\subsubsection{Hasil Observasi Aktivitas Siswa}

Hasil observasi aktivitas belajar siswa dari siklus ke siklus dapat dilihat pada gambar 3 . sebagai berikut :

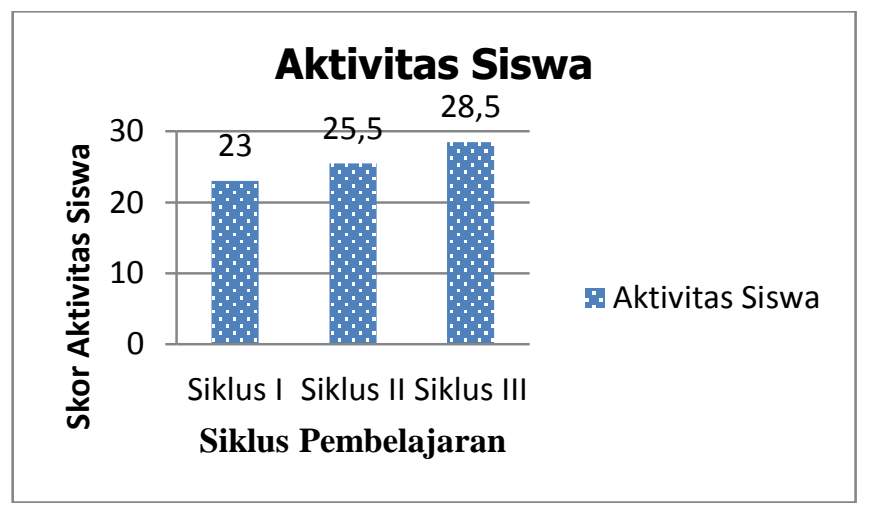

Gambar 1. Aktivitas Siswa 


\subsubsection{Hasil Observasi Keterampilan Proses Sains}

Hasil observasi keterampilan proses sains tiap aspek dapat dilihat pada gambar 4. sebagai berikut :

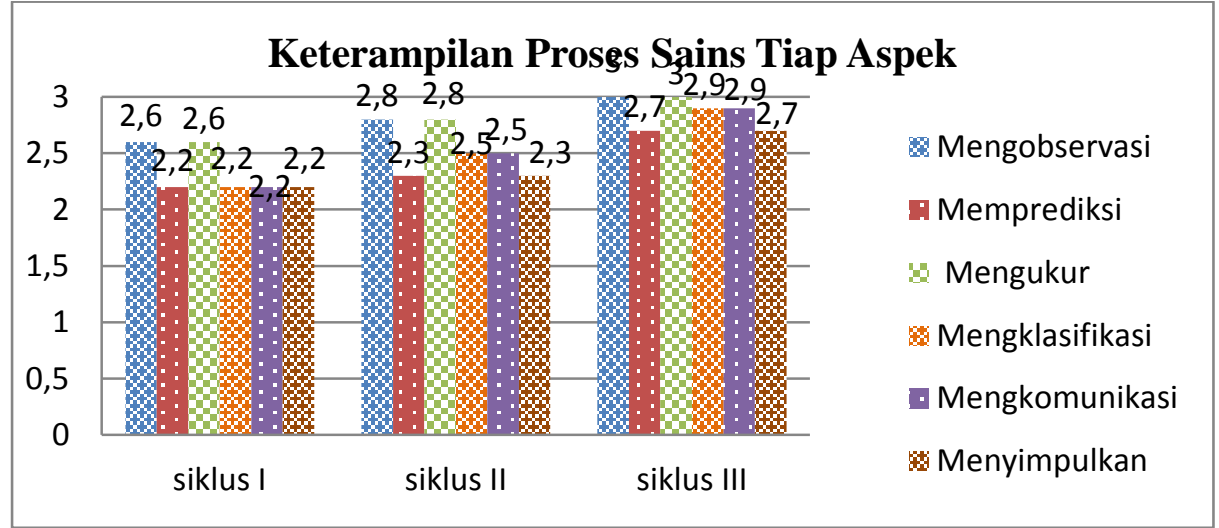

Gambar 2. Keterampilan Proses Sains Tiap Aspek

Hasil observasi keterampilan proses sains dari siklus ke siklus dapat dilihat pada gambar 5. sebagai berikut :

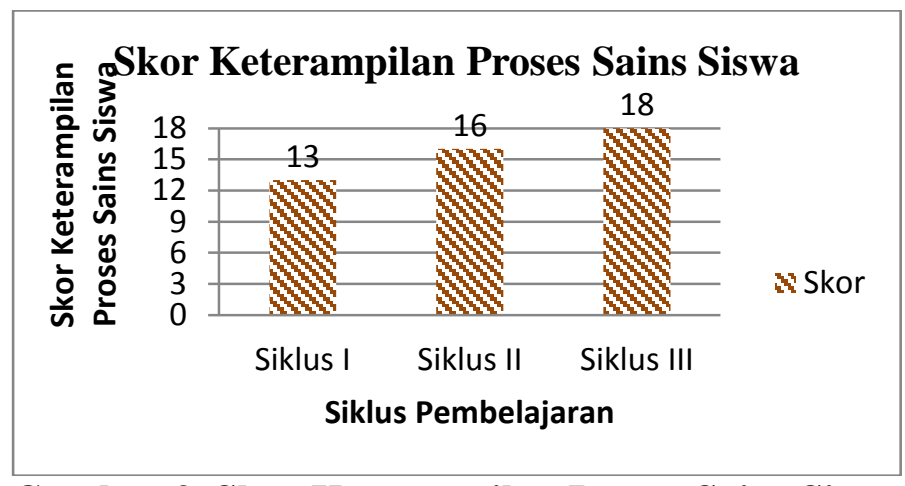

Gambar 3. Skor Keterampilan Proses Sains Siswa

Hasil belajar siswa dari siklus ke siklus dapat dilihat pada gambar 6 sebagai berikut:

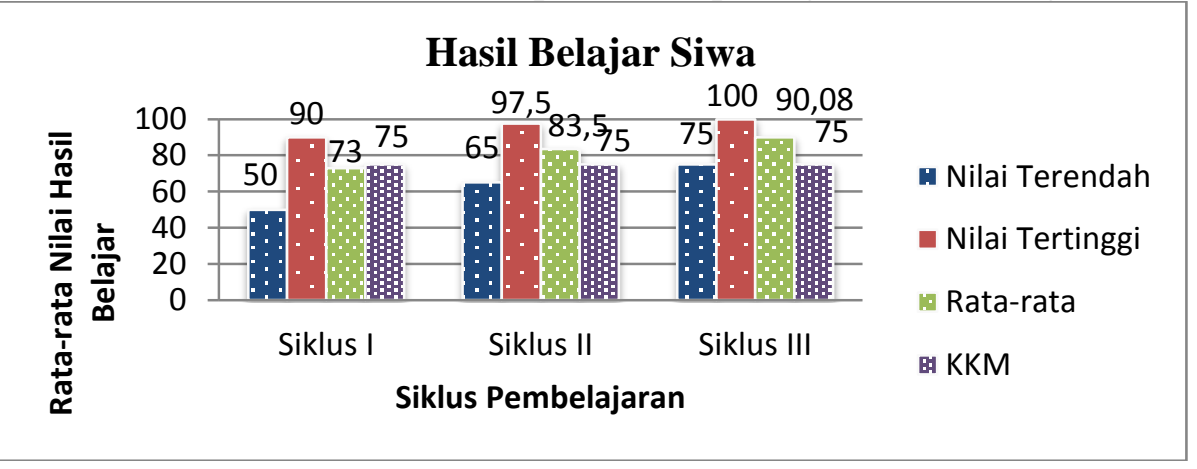

Gambar 6. Hasil Belajar Siswa

\subsection{Pembahasan}

\subsubsection{Deskripsi Aktivitas Siswa}

Berdasarkan gambar 4.1. telah diperoleh hasil aktivitas siswa setiap siklusnya yaitu siklus I sebesar 23 dalam katagori cukup, pada siklus II sebesar 25,5 dalam katagori baik serta siklus III sebesar 28,5 dalam katagori baik. Ada 10 aspek aktivitas siswa yang telah diamati pada setiap siklus. Semua aspek aktivitas tersebut telah dilaksanakan dan terdapat beberapa kekurangan. Sehingga dilakukan refleksi pada siklus I yang bertujuan untuk memperbaiki proses pembelajaran pada siklus ke II. Pada siklus II aktivitas guru dan siswa dalam proses 
pembelajaran masih terdapat kekurangan-kekurangan dan harus di lakukan refleksi guna memperbaiki siklus selanjutnya. Setelah dilakukan refleksi pada setiap siklus, aktivitas siswa dapat meningkat yaitu siklus III lebih besar dari siklus I dan II.

Berdasarkan uraian di atas, aktivitas belajar siswa dalam mengikuti kegiatan pembelajaran dengan menggunakan penemuan terbimbing untuk memperbaiki proses pembelajaran di kelas X MIA-1 SMA Negeri 1 Kota Bengkulu telah mengalami perbaikan dan peningkatan. Hal ini sesuai dengan apa yang dikemukakan oleh Penelitian Watyna, Siska dan Eidi (2012) menyimpulkan bahwa bahwa model pembelajaran guided discovery dapat meningkatkan aktivitas belajar siswa.

\subsubsection{Deskripsi Keterampilan Proses Sains}

Berdasarkan gambar 4.4. telah diperoleh hasil pengamatan keterampilan proses sains siswa peraspek yang selama III siklus menggunakan model penemuan terbimbing telah mengalami peningkatan pada setiap siklusnya. Skor tertinggi terdapat pada aspek Mengobservasi/mengamati dan skor terendah pada aspek memprediksi, karena pada keterampilan proses sains ini siswa belum bisa membuat hipotesis berdasarkan rumusan masalah percobaan.

Langkah memprediksi diperoleh dalam katagori cukup tetapi telah terjadi peningkatan pada siklus II dan siklus III. Pada siklus I siswa masih bingung untuk memberikan prediksi/hipotes percobaan tentang hubungan fakta, konsep dan prinsip ilmu pengetahuan dengan menghitungkan penentuan secara tepat sesuai tujuan percobaan. Pada siklus II dan siklus III siswa sudah mulai mengerti cara membuat hipotesis dengan melakukan diskusis bersama kelompok dalam memberikan prediksi/hipotes percobaan tentang hubungan fakta, konsep dan prinsip ilmu pengetahuan dengan menghitungkan penentuan secara tepat sesuai tujuan percobaan.

Selanjutnya aspek mengukur dalam katagori baik dalam setiap siklusnya. Siswa bersama kelompok sudah bisa melakukan pengukuran walaupun masih ada siswa yang belum terampil dalam melaksanakan pengukuran pada siklus I seperti saat merangkai alat. Namun, pada siklus II dan III siswa sudah terampil dalam mengukur dan merangkai alat dan bahan percobaan.

Aspek mengklasifikasi dalam katagori cukup pada siklus I, siswa bersama kelompok belum bisa menghubungkan hasil pengamatan dengan persamaan yang harus digunakan. Namun ada beberapa siswa bersama kelompok yang sudah baik dalam keterampilan proses sains pada aspek mengklasifikasi. Pada siklus II dan siklus III sudah dalam katagori baik, siswa bersama kelompok sudah bisa menghubungkan hasil pengamatan dengan persamaan yang harus digunakan.

Aspek mengkomunikasi dalam katagori cukup, siswa bersama kelompok belum bisa memberikan jawaban yang tepat terhadap pertanyaan yang diberikan di LKS namun ada siswa yang sudah baik dalam memberikan jawaban. Namun pada siklus II dan III siwa sudah bisa menjawab pertanyaan dengan baik sesuai dengan pertanyaan yang diberikan terkait percobaan yang telah dilakukan.

Aspek terakhir, yaitu menyimpulkan dalam katagori cukup pada siklus I. Hal ini karena masih banyak siswa bersama kelompok yang belum paham cara membuat kesimpulan yang seharusnya di sesuaikan dengan tujuan dan rumusan masalah. Namuan pada siklus II dan III siswa bersama kelompok berdiskusi dengan baik dalam membuat kesimpulan sesuai dengan tujuan percobaan.

Pada siklus I keterampilan proses sains siswa sudah dalam katagori cukup, skor keterampilan proses sains siswa yaitu sebesar 13 dengan skor tertinggi berada pada aspek keterampilan mengobservasi dan mengukur dalam kategori baik. Memprediksi, mengklasifikasi, mengkomunikasi dan menyimpulkan masuk dalam kategori cukup. Keterampilan proses sains siswa dikatakan baik bila jumlah nilai siswa berada pada skor 1418 pada setiap aspek keterampilan proses sains dan keterampilan proses sains siswa dikatakan 
cukup bila jumlah nilai sikap ilmiah berada pada skor 10-13 dan katagori kurang pada skor 69. Pada siklus I siswa yang masuk dalam katagori keterampilan proses sains yang baik sebanyak $14(53,3 \%)$ orang siswa, dan dalam katagori cukup sebanyak 14 (46,6 \%) orang siswa.

Pada siklus II keterampilan proses sains siswa sudah lebih baik dan meningkat bila dibandingkan siklus I. Skor keterampilan proses sains siswa pada siklus II yaitu 16 dengan katagori baik. Skor tertinggi pada siklus II ini masih berada pada aspek mengobservasi/mengamati dan mengukur. Terjadi peningkatan pada aspek mengklasifikasi dan mengkomunikasi. Keempat aspek ini berada pada katagori baik, sedangkan aspek memprediksi dan menyimpulkan masih dalam katagori cukup. Pada siklus II jumlah siswa yang masuk dalam katagori baik sebanyak $23(76,6 \%)$ orang siswa, dan siswa yang masuk katagori cukup $7(23,3 \%)$ orang siswa dengan demikian secara keseluruhan siklus II dalam katagori baik.

Pada siklus III keterampilan proses sains siswa meningkat lagi bila dibanding siklus II dimana skor yang diperoleh sebesar 18 dan dalam katagori baik. Pada siklus III ini semua aspek keterampilan proses sains masuk dalam kategori baik. Seluruh keterampilan proses sains siswa baik, artinya pada siklus III ini sebanyak 30 (100\%) orang siswa mendapatkan kategori baik. Hal ini sesuai dengan apa yang dikemukakan oleh penelitian Rachayuni (2015) menyimpulkan bahwa pembelajaran guided discovery dapat meningkatkan hasil belajar dan keterampilan proses sains siswa.

\subsubsection{Deskripsi Hasil Belajar}

Berdasarkan gambar 3.4. diketahui bahwa adanya peningkatan hasil belajar pada tiap siklus. Pada siklus I nilai rata-rata sebesar 73, meningkat pada siklus II dengan nilai rata-rata 83,5 dan meningkat lagi pada siklusi III dengan nilai rata-rata sebesar 90,08. Adapun katagori yang diperoleh pada siklus I masih tidak tuntas, namun pada siklus II dan III terjadi peningkatan sehingga hasil belajar dalam katagori tuntas.

Pada siklus I perolehan nilai rata-rata siswa yaitu sebesar 73 dan dalam katagori tidak tuntas artinya secara rata-rata klasikal siswa belum menguasi materi yang telah diajarkan guru. Nilai terendah yang diperoleh pada siklus I ini adalah sebesar 50 dan tertinggi sebesar 90. Jumlah siswa yang tuntas pada siklus I ini sebanyak 15 siswa dari 30 siswa. Hasil belajar pada siklus I ini, daya serap sebesar 73\% dan ketuntasan belajar sebesar 50\% sehingga secara klasikal hasil belajar kognitif siswa tidak tuntas. Karena ketuntasan belajar siswa Atau Jumlah siswa yang mendapat nilai akhir $\geq 75$ hanya mencapai $50 \%$ sedangkan kriteria ketuntasan belajar klasikal adalah apabila siswa yang mendapat nilai $\geq 75$ telah mencapai $80 \%$.

Pada siklus II perolehan peningkatan nilai rata-rata siswa yaitu sebesar 83,5 dan dalam katagori tuntas artinya secara rata-rata klasikal siswa sudah memahami materi yang telah diajarkan oleh guru. Nilai terendah yang diperoleh siswa pada siklus II adalah 65 dan nilai tertinggi adalah 97,5 dengan jumlah siswa yang tuntas sebanyak 26 orang siswa. Pada siklus II ini siswa sudah mulai terbiasa dengan proses pembelajaran menggunakan model penemuan terbimbing dan memahami materi yang diajarkan ini dilihat dari peningkatan daya serap siswa sebesar 83,5\% dan ketuntasan belajar sebesar 86,6\% sehingga secara klasikal hasil belajar siswa sudah tuntas karena kriteria ketuntasan belajar siswa itu apabila siswa yang mendapat skor $\geq 75$ mencapai $80 \%$.

Pada siklus III diperoleh nilai rata-rata sebesar 90,08 dan dalam katagori tuntas. Jumlah siswa yang tuntas juga meningkat, yaitu seluruh siswa bisa mengerjakan tes dengan baik. Nilai terendah yang diperoleh siswa pada siklus III yaitu 75 dan nilai tertinggi yaitu 100 . Daya serap menigkat sebesar 90,08\% dan ketuntasan belajar sebesar $100 \%$ secara klasikal hasil belajar siswa telah tuntas, secara klasikal itu terlihat pada ketuntasan belajar siswa atau jumlah siswa yang mendapat skor $\geq 75$ telah mencapai $100 \%$. Peningkatan yang terjadi pada setiap siklus karena pada awalnya siswa belum terbiasa dengan model yang diajarkan dan mulai terbiasa pada siklus II dan III sehingga materi yang diajarkan bisa dipahami. 
Hal ini sesuai dengan apa yang dikemukakan oleh penelitian Syaifulloh dan Jatmiko (2014) menyimpulkan bahwa pembelajaran dengan model guided discovery mengalami peningkatan hasil belajar dan juga Rachayuni (2015) menyimpulkan bahwa pembelajaran guided discovery dapat meningkatkan hasil belajar dan keterampilan proses sains siswa.

\section{Kesimpulan dan Saran \\ 4.1 Kesimpulan}

Berdasarkan hasil penelitian dan pembahasan, diperoleh kesimpulan sebagai berikut; (1) Penerapan model penemuan terbimbing pada konsep getaran harmonik sederhana dapat meningkatkan aktivitas belajar siswa kelas X MIA-1 di SMAN 1 Kota Bengkulu, (2) Penerapan model penemuan terbimbing pada konsep getaran harmonik sederhana dapat meningkatkan hasil belajar siswa kelas X MIA-1 di SMAN 1 Kota Bengkulu, (3)Penerapan model penemuan terbimbing pada konsep getaran harmonik sederhana dapat meningkatkan keterampilan proses sains siswa kelas X MIA-1 di SMAN 1 Kota Bengkulu.

\subsection{Saran}

Berdasarkan penelitian yang telah dilakukan, disarankan perbaikan penelitian dimasa yang akan datang, yakni (1) Diharapkan untuk penelitian-penelitian selanjutnya, semua kelengkapan yang dibutuhkan dalam penelitian dipersipakan dengan semaksimal mungkin agar penelitian dapat berjalan dengan maksimal, (2) Bagi peneliti selanjutnya sebaiknya memberikan bimbingan dan perhatian yang lebih merata pada setiap kelompok sehingga mengurangi peluang siswa bermain-main saat pembelajaran berlangsung.

\section{Daftar Pustaka}

[1] Widiasworo, E. (2017). Strategi dan Metode Mengajar Siswa Di Luar Kelas (Outdoor Learning) Secara Aktif, Kreatif, Inspratif, \& Komunikatif. Yogyakarta: Ar-Ruzz Media.

[2] Arikunto. (2010). Prosedur Penelitian Suatu Pendekatan Praktek. Jakarta: Rineka Cipta.

[3] Purwanto, A. (2009). Penerapan Media Jejaring Sosial "Facebook" terhadap Mata Kuliah Termodinamika. Jurnal Exacta, Vol.VII No 2, 1412-3617.

[4] Widiyanto, M. A. (2013). Statistika Terapan. Jakarta: PT Elex Media Komputindo. 